\title{
On becoming the hands and feet of Christ in an AIDS-ridden community in Swaziland - A story of hope
}

A van Wyngaard ${ }^{1}$

(Swaziland Reformed Church)

Kuba yini nje kuhlekelela kwemntfwana londzindzile, kudzabuka ngekhatsi kwebulukhuni bako konkhe lokukhatsate umntfwana longenacala, kulomntfwana, kwemukela lokutsite, ukuva kunjengesibusiso? (What is it about a needy child's smile, breaking through the resistance of all that has trauma-tised an innocent child, that to receive it feels like a blessing?)

(About Us / Ngatsi - Stories from orphaned and vulnerable children in Swaziland)

\section{ABSTRACT \\ On becoming the hands and feet of Christ in an AIDS-ridden community in Swaziland - A story of hope}

In terms of the social involvement of the Christian church within the community, it would not be an overstatement to say that never before in history has there been a greater challenge facing the church than the present, finding a way to bring hope to those suffering due to the HIV/AIDS pandemic. Yet, in spite of the enormity of this pandemic, it is possible to make a huge difference in people's lives, making use of a few willing people and a fairly conservative budget.

In this article the author attempts to describe the way in which a very small congregation, where the average weekly attendance at church services is seldom more than fifty people and where nearly all members live close to or under the breadline, started making a noticeable difference in their community. Motivated by God's love for them, they decided to share this love in a practical way with all those in the community suffering due to HIV/AIDS and other serious illnesses. This is a story of hope, not only for those who receive help, but even more so, for those who want to give help.

\section{BACKGROUND}

For the thousands of people visiting Swaziland annually, this small landlocked country situated between South Africa and Mosambique,

1 Research Associate, Department of Science of Religion and Missiology, University of Pretoria. 
portrays the image of stability, friendliness and a comfortable mixture of cultures, where the West and Africa seem to mingle with very little tension. Not far from the two main ports of entry, the Oshoek border post and the Matsapha airport, a wealth of tourist attractions can be found. These include the Royal Swazi Sun, best known for its luscious green golf course situated within the Ezulwini Valley (Valley of Heaven) and a number of game reserves where visitors can relax in typical African accommodation while being spoilt with good service and almost all of the amenities one would expect to find at home. There is even a fairly good chance that all of the "big five" would be seen at close range. This is Swaziland as most foreign visitors experience it.

But a few kilometres from these popular tourist attractions, another picture unfolds. This is a picture of poverty and drought, of widows and orphans, of hospitals and VCT (Voluntary Counselling and Testing) clinics where people with hopeless faces sit and wait for a chance to see a sister, not knowing what she will say to them. Here, to be positive has obtained a negative meaning, and to be negative is considered to be a blessing, as positive and negative refer, not so much to one's attitude towards life, but rather to one's HIV status. This is the Swaziland much better known to the indigenous Swazi population, the Swaziland many missionaries working in this country have come to know, the Swaziland where an entirely new type of ministry is needed if the church wishes to remain relevant within this society - the Swaziland in the process of being devastated by the HIV/AIDS pandemic.

Swaziland is a small country, measuring 17363 square kilometres. It is about $1,5 \%$ the size of South Africa, which borders Swaziland on the north, west and south and it is fifty times smaller than Mocambique on its Eastern border. The country has a population of approximately 1 million people, leading to a population density of around 59 people per square kilometre, somewhat higher than South Africa with its 36 people per square kilometre. However, what is extremely distressing about the number of people in Swaziland is the steady decrease in population growth since the early 1980s. Accurate statistics on Swaziland's present population numbers are impossible to find. Swaziland has a census approximately every ten years. The last was held in 1997. To fully comprehend the impact of HIV/AIDS on this country, one will therefore have to await the results of the 2007 census. However, estimates by various reputable organisations such as UNAIDS, WHO (World Health Organisation), NERCHA (National 
Emergency Response Committee on HIV/AIDS) and SNAP (Swaziland National AIDS Program) all indicate the seriousness of the situation with which Swaziland is faced. According to the Central Statistical Office which works with population numbers in Swaziland, the projected population growth in Swaziland has been reducing since 2001 by approximately $0,2 \%$ per year, bringing the official population growth rate to $1,7 \%$ in 2005 , compared to $3,2 \%$ in the years preceding 1986, the year when the first cases of HIV were identified in the country. However, this projection by the Central Statistical Office is still much higher than the figure published in the 2006 report by UNAIDS which currently sets the population growth rate at only $0,2 \%$ (UNAIDS 2006a:460).

Whatever the true case may be, the fact remains that, on ground level, people are seeing their friends and family members becoming ill and dying at a horrific rate. According to UNAIDS (2006a:460) a total number of 220,000 people in Swaziland are HIV-positive. The $8^{\text {th }} H I V$ Sentinel Serosurveillance Report which was printed in 2002 shows that, of those who are considered to be in the sexually active age group (1549), about 38,6\% are HIV-positive (Kingdom of Swaziland 2002:26) and an estimated 16000 people die annually due to AIDS-related diseases - more than 40 people per day! Since 2004 Swaziland has found itself in the unenviable position of being the country with the highest HIV prevalence rate in the world, after Botswana's efforts to fight the disease caused its adult HIV/AIDS prevalence rate to decline from $38,8 \%$ to $37,5 \%$. Swaziland's rate, however, has remained stable (Kaiser Family Foundation 2004).

When the first cases of HIV were identified in Swaziland in 1986, little attention was given to this. The same happened in the rest of the world ${ }^{2}$. The few who dared to warn people about a coming disaster were made out to be doom prophets ${ }^{3}$. Swaziland was still in a state of total denial concerning this disease. But the statistics kept on escalating. Within five years, 584 people were known to be HIV-

2 Randy Schilts documented the history of the first years of this epidemic in his excellent book And the Band played on, in which one of the main themes is the inability of governments and politicians to address this problem in time so as to make a difference.

3 One pastor in Swaziland I know soon earned the nickname of Umfundisi AIDS ("Reverend AIDS") because of his ongoing preaching and teaching about AIDS. 
positive, 62 people already had full-blown AIDS and at least 43 people had died due to AIDS-related diseases. In 1992, the SCC (Swaziland Conference of Churches) decided to devote its General Assembly entirely to the topic of AIDS ${ }^{4}$. On the agenda for the assembly were the following three topics:

1 Background of and future challenges for AIDS;

2 The fight against AIDS;

3 Counselling people in an AIDS era.

It would be wonderful to say that this conference brought a change in the attitude of churches and their leaders in Swaziland towards those infected with and affected by HIV/AIDS, but unfortunately this did not happen. Although a large number of church leaders attended the conference, for many AIDS continued to be God's judgement upon sinners. The country was still in denial of the reality of AIDS and it became increasingly difficult to get accurate reports on HIV and AIDS statistics $^{5}$. Although many church leaders from a variety of denominational backgrounds did get involved in the HIV/AIDS crisis, the church body in Swaziland as a whole still lacked the ability to coordinate a united process in order to address the pandemic. The most positive move forward in this regard was the forming of the Church Forum in March 2005, which is the official Christian organisation representing the Council of Swaziland Churches, the League of African Indigenous Churches, and the Swaziland Conference of Churches. It was established with its main aim to work directly on programs and

4 Prof Willem Saayman, at that stage professor of Missiology at UNISA was one of the few South African theologians who, during the early years, was able to foresee what the consequences of this epidemic would be if something was not done in time. He was invited to introduce the discussions on this topic. Due to the untimely death of David Bosch shortly before the meeting was to be held, Prof Saayman had to take the position as head of the Department of Missiology and had to decline the invitation to address the church in Swaziland. On short notice the author of this article was then asked to lead the discussions on AIDS during the General Assembly of the SCC.

5 Up to 1991 statistics seem to be fairly accurate. From 1992 onwards the numbers of AIDS cases that were reported are obviously inaccurate. To illustrate the point, the numbers of full-blown AIDS cases reported to the World Health Organisation for those early years were as follows: 1987 (1); 1988 (2); 1989 (7); 1990 (20); 1991 (31); 1992 (216); 1993 (165); 1994 (120); 1995 (154); 1996 (613); 1997 (1466); 1998 (733) and 1999 (1259) (WHO 2004:6). 
projects associated with HIV/AIDS on behalf of the church in Swaziland (Wilson \& Wilson 2005), although a personal conversation with Bongani Langa, co-ordinator of the Church Forum, revealed that there is still very little happening concerning the church's involvement in the AIDS pandemic. While a number of organisations, such as UNAIDS, WHO, UNICEF and NERCHA became actively involved in the fight against HIV/AIDS, the Christian church failed to realise the potential it had in its midst to make a difference in Swaziland. As the World Council of Churches (2001:3) remarked:

The churches have strengths, they have credibility, and they are grounded in communities. This offers them the opportunity to make a real difference in combatting HIV/AIDS. To respond to this challenge, the churches must be transformed in the face of the HIV/AIDS crisis, in order that they may become a force for transformation - bringing healing, hope, and accompaniment to all affected by HIV/AIDS.

What follows is the story of one congregation that decided to become such a force for transformation. There are many similar stories to tell. This story is about a small group of men and women who had the vision "to become the hands and feet of Christ" within the community surrounding their church.

\section{DWALENI}

Dwaleni (the place of the rock) is a rural area in the southern district of Swaziland - known as Shiselweni - about $10 \mathrm{~km}$ from the main town of this district, Nhlangano. (Nhlangano means the meeting place, which refers to the historic meeting which took place in this town between king George VI of England and the former king Sobhuza II of Swaziland in 1947). Dwaleni is also the name of one of the congregations of the Swaziland Reformed Church, where approximately fifty people gather every Sunday for a church service, singing traditional siSwati spiritual songs in preparation for the Word of God to be proclaimed.

The church members at Dwaleni are mostly subsistence farmers, meaning that they live on a small portion of land granted to them by the local chief, usually large enough for them to plant maize to feed their families as well as allowing a few head of cattle and some goats to graze. Some of these people are fortunate enough to have a job in nearby Nhlangano. Probably a more than average number of these 
members attend church on a Sunday and during the week they often attend prayer meetings or other functions arranged by the church.

Dwaleni is also one of the places in Swaziland which has been the hardest hit by the HIV/AIDS pandemic. On one particular Saturday in 2005, I was visiting some of the members at Dwaleni. We met informally in the church, together with some people from a Dutch Reformed congregation in South Africa who had come to visit us. One of the South Africans asked the question: "Do you have many funerals in your area?" One of the Swazi members answered: "This morning we buried two people. Tomorrow morning we will bury two more people. For next Saturday two funerals have already been arranged and another two has been arranged for next Sunday. And every weekend it is the same" ${ }^{\text {. }}$. This is happening in an area measuring only a few square kilometres!

Shortly before this meeting took place, I had had the privilege of visiting one of the so-called "migrant" churches in Rotterdam in the Netherlands. Many of the residents of Rotterdam are from other countries and within this city a network of "migrant" churches was established, meeting the needs of the diversity of people living there. One of these churches is the Scots International Church Rotterdam. This church has its origin in the Church of Scotland, describing itself as "a Protestant Church in the Presbyterian tradition". The mission statement of this church reads as follows:

We share with other churches a concern for the poor, the homeless and uprooted, and work for a just and peaceful world. As part of the world church we seek to work with and alongside our partners across continents and traditions and to share with congregations in Scotland the joy of our unity in Christ.

\section{PREPARING THE CHURCH FOR ITS TASK}

After meeting with the pastor, Robert Calvert, and hearing how this church had put their vision into practice in Rotterdam, I returned to Swaziland with the desire to see the congregation at Dwaleni

$6 \quad$ In Swaziland funerals usually take place at sunrise on either a Saturday or a Sunday.

7 Refer to http://www.scotsintchurch.com/index.php for more details on this specific church. 
transformed to become bearers of God's compassion within their community. The first step was to discuss this vision with the leaders of the church. The Swazis are naturally very caring people (as are most African people), and the well-being of the community is often more important than the need of the individual ${ }^{8}$. It was therefore no surprise that the church leaders were extremely excited about the prospect of the church "officially" reaching out to those in need. The vision we had for the church was formulated in the words: Becoming the hands and feet of Christ in this community.

The next step was to invite the church members to come on board. For the following months every sermon that was preached at Dwaleni focussed on God's compassion for those in distress. From both the Old and the New Testament this specific aspect of God's caring for people was emphasised, and those attending the church service were challenged to adopt the same attitude towards those in need. After several months the church members were asked to remain behind after the service and the vision of the church leaders was then explained to them. Once again there was great excitement among the group. Up to that point they had been confronted by the needs of the community, doing the little they could. The idea that the church would not only lend a helping hand, but would empower people to do much more than they had been able to do in the past, sounded very positive to them.

In order to determine the best possible route forward, an AIDS conference was arranged for 19 November 2005 and an open invitation was given to all who were interested to attend. About forty people turned up for the conference. Speakers from religious, medical and welfare backgrounds were asked to introduce a number of topics related to the issue of HIV/AIDS, after which all those who were present divided into smaller groups to decide on a future plan. The decision was unanimous that the best route forward would be to start with a home-based caring project at Dwaleni ${ }^{9}$.

It is essential within rural Africa that any decision which will have an influence on an entire community first needs to be communicated to the chief of the area, who will then discuss it with the

8 Attie van Niekerk (1992) gives a number of interesting examples of this attitude in his book "Sáám in Afrika”.

9 Refer to www.swazimission.co.za/English/AC-2005-11-19.htm for a full report on this meeting. 
residents living there. In this way recognition is given to the authority of the chief and any future planning will become much easier, knowing that the community leaders will give their support to such a project. In our case we were in the fortunate position that the local acting councillor, Robert Mkhonta, not only attended the AIDS conference, but had already started with a small home-based caring project. He had a group of twelve care-givers visiting people in their homes once a week. Without further ado he gave us permission and his blessing so that we could immediately move forward to the next phase of our planning.

Although we were fortunate in being able to avoid the timeconsuming process of getting permission from the chief to proceed with our plans, we did however realise that we could not start with a new home-based caring project while other people were already involved in such a project in the area. Africa has a saying: "If you want to go fast, go alone. If you want to go far, go together" (Christianity Today Editorial 2006). We therefore, through the acting councillor arranged to meet the existing care-givers on 3 December 2005. Our intention was mainly to hear what they were already doing and also to see if we could join hands and do this work together with them, instead of having two similar projects running in the same area. When the meeting started, I was asked to act as chairman. I explained to those present what we wished to do, emphasising that this would not be something done mainly for the benefit of our own church but for the benefit of the entire community. The group of twelve people who were already involved in home-based caring in that area were then given ample time to share with the rest exactly what they were doing, what problems they faced and what their specific needs were. It soon became clear that they had two basic needs: The first was a need for training in order to do this work more efficiently and the second was a need for food, as many people with whom they had regular contact were so ill that they could no longer plant maize for their own use or take care of their vegetable gardens ${ }^{10}$. As the stories were told, the realisation dawned that we were faced with a crisis within the community, much greater than we could ever have imagined. Stories were told of children having to take care of their parents dying of AIDS, stories of orphans left behind who have to fend for themselves, a story of one family of six orphans of whom the

10 Refer to www.swazimission.co.za\English $\backslash$ AC-2005-12-03.htm for a full report on this meeting. 
oldest at eighteen years of age had just recently finished grade one while none of the brothers and sisters had ever been to school, stories of people who urgently need to go to hospital, but due to lack of transport find it impossible to go and therefore die at home, stories of orphans chased from school because they do not have the necessary funds to pay for their school fees.

Trying to calculate how many people in the area are HIV-positive or how many orphans there are, seemed to be impossible. Dwaleni falls within a specific Inkhundla (constituency). From what we gathered from the people present, we could expect to find between 300 and 400 orphans in this Inkhundla. According to the 2006 report of UNAIDS (2006a:460), Swaziland has about 63000 orphans, (although the number could be as high as 77000 ) which means that nearly $8 \%$ of the total population and $15 \%$ of those under the age of seventeen are already orphans ${ }^{11}$. Whatever the true figures may be, the cry for assistance was loud. After some more discussion, it was decided that the most urgent need was to get people trained in order to start an efficient home-based caring project. Project Support Association Southern Africa (PSA) ${ }^{12}$ had already offered to help with the training of these potential care-givers and all that remained was to confirm a date when training would commence, early in 2006.

During the week of 23-27 January 2006 the first thirty-two caregivers were trained at the Swaziland Reformed Church's building at Dwaleni. The training was done by two representatives from PSA. To ensure that proper recognition would be given to the care-givers, several community leaders were invited to attend the opening session of the training, including the local Member of Parliament. The training covered all topics relevant for those who would be working with the people of the community in the future. Keeping in mind that many of these volunteers had not had much school training, a fine balance had

11 'It is telling that there is no 'western' concept of orphan in Swazi culture. Traditionally a child whose parents had died would be cared for by the extended family, but now the numbers of orphans and vulnerable children are overwhelming the capacity of the extended family to cope. Elderly grandparents or relatives who are left to look after orphaned children when parents die from AIDS-related illnesses, often simply do not have the energy or means to grow enough food" (UNAIDS 2006b:11).

12 PSA is situated in Bethal, Mpumalanga (South Africa). The director is Corrie Oosthuizen and she can be contacted at coosthuizen@gmx.net 
to be kept between high quality training while keeping the contents simple enough so that all could understand. It was a great advantage to be able to entrust the training to people who do this on a regular basis.

One of the amazing things that happened during the training, which we did not plan for but which we realised afterwards would be essential if we wanted this project to be successful, was that a number of men also volunteered to help with the project. To a very large extent Swaziland is a male dominated society where it is common that men expect their wives and their daughters to serve them. To have six men join in the training in order for them to serve others in the community was therefore nothing less than a miracle.

An important issue which was discussed during the training was whether the care-givers would be paid for their work. All of the trainees said that they did not expect anything in exchange for what they were going to do, but we also realised that it would be unfair to expect these people to work a minimum of twelve hours per week without receiving anything in return. Through PSA we were able to find donors who were willing to pay a small stipend ${ }^{13}$ to each of these care-givers, and from time to time donations in the form of food parcels are also handed out to them as a way of thanking them for what they are doing.

Once the training was completed we decided to have a special church service where the entire community was invited to attend, together with the different leaders within the community (chiefs, local politicians and other acknowledged leaders). Through this we wanted to achieve three goals: Firstly, we wanted to dedicate these people and what they were planning to do to the Lord. Secondly, we wanted the community to realise that what we are doing, was because of what Jesus Christ had done for us and expects from us. Thirdly, we wanted the community to take note of the care-givers and to realise that they were being sent out into the community for their benefit.

\section{THE HOME-BASED CARING PROJECT}

At present thirty-two care-givers are visiting people in the community on a daily basis. One of them, Mildred (Shorty) Khumalo, has been chosen to act as co-ordinator of the group. The area was divided into zones and, as far as possible, we try to use care-givers in zones close to

13 At the time of writing this article, each care-giver received R150-00 (US\$22) per month. 
their homes so that they do not need to waste time and money in travelling to and fro. We recommended that each volunteer take responsibility for no more than five people, but in effect most of the care-givers visit between eight and ten people every week - some daily and others less often. Their work consists of taking medicine to the homes, ensuring that the medicine is taken, sometimes giving food if the patients (or clients, as we refer to them) are unable to provide for themselves, cleaning and washing clients who are unable to care for themselves, applying ointment to open sores and even fitting adult diapers if the clients have come to the point where they no longer have control over their bladders or bowel movements. Furthermore they have become ears to listen to these people who open their hearts and share the pain and uncertainty of the situation with which they are faced. Because of the trust which exists between the care-givers and the clients they visit, this has also become an ideal time to share Biblical truths with each other, as well as to pray together.

Probably the most important decision made during the early days of this project, was that the care-givers may only work four days per week. One day in a week, in our case every Friday, is set aside as a day when all the care-givers come together for a few hours. What is often forgotten is that the care-givers build extremely strong relationships with the clients they are caring for. However, inevitably, all of those infected with HIV are going to die - some sooner and some later. On average one or two of the clients in the care-giving program die every week. While professional medical personnel could probably be expected to remain largely untouched by the death of a patient, one cannot expect the same from these care-givers. On the contrary, because they are working with neighbours, friends and even family members, it is entirely impossible for them not to be deeply touched by the death of any of these people. Therefore, our Friday sessions are times of giving official reports required by donors, sharing stories with each other, but also times of debriefing where people are allowed and encouraged to speak about the emotions that they experience while doing this work. One of our donors specifically supplies food for these meetings, which means that every Friday a meal is cooked and all those present eat together - an important part of Swazi culture and an important part in the bonding process of the care-givers. We were warned that, should this form of support be neglected, chances are great that the entire program might eventually collapse as the emotional stress which the care-givers experience becomes too much for them to 
cope with. Obviously time is also spent praying for the project, committing each care-giver and each client to the Lord.

As the program took further shape, the following mission statement was formulated:

In a community devastated by poverty, sickness, broken families and death, we want to bring back true Christian hope, not only through our words but also - following the perfect example of our Lord, Jesus Christ - by reaching out in love to those in need, comforting and supporting them by all means available to us.

As word spread about the church reaching out to the community, people from surrounding communities have made contact with us to request help in their areas as well. A decision has already been made to train a further eighteen care-givers, which would bring the total number of care-givers to fifty. We will then divide the group into two, with two co-ordinators and twenty-five care-givers in each group. Using this method, it will be possible to expand the service without jeopardising the quality which we strive to maintain.

\section{THE FEEDING PROJECT FOR VULNERABLE CHIL- DREN}

Shortly after the project started running, we were confronted with another challenge. Many children in the Dwaleni area suffer from severe malnutrition. This includes (but is not restricted to) orphans. Community leaders approached the church and asked that a feeding project be started at the church where one balanced meal could be served to these children every day. Knowing that this could erupt into an enormous project once word went round that a free meal was available, the care-givers decided that they would start by cooking one meal twice a week. The Inkhundla offered to supply a certain amount of mealie meal (maize) each month to enable the church to supply food to the children. A few women from the church who were not yet part of the care-giving program, were asked to cook the food. An agreement was made with them that, in exchange for cooking the food, they would also be free to feed themselves and their families from the food they prepared. This was a great incentive for them.

As expected, word quickly spread that food was being served at the church. To avoid stigmatising the orphans and other vulnerable children, it was decided that no child would be turned away should they want food. A problem which did arise, however, is that many adults 
started misusing these facilities, turning up every afternoon for a free lunch while it was clear that they were still healthy and even employed. A decision was taken that even these people would still be fed, but eventually their numbers decreased, as the food being offered is fairly basic, concentrating more on the need for a healthy and balanced diet rather than on extras. Very soon about two hundred and eighty children were being fed twice a week. Children wanting to be fed have to bring their own bowls and many also take food back to their homes to share with their families.

When it became clear that the project was working to our satisfaction, the project leaders decided that they wanted to increase the number of days on which food is supplied to five days per week. After calculating the costs involved, it was agreed that, through certain donations which were being given to the project, it would be feasible to continue with the expansion of the feeding project.

Three days after making this decision, we were offered as much mealie meal as we needed through the World Food Project. This served as a tremendous motivation for all those involved with the project and we all experienced this as confirmation from God that we were doing the right thing. At the same time we also immediately decided that the money that we would have spent on buying mealie meal, would now be used to supplement the food which we were already giving, in order to ensure that each child receives the correct vitamins and other essential minerals to live a healthy life. To assist us in deciding what to buy, we contacted a Christian dietician. She offered her services free of charge, not only to give us information, but also to train the people involved in the home-based caring, as well as the feeding projects, so that they could better understand what the needs are and how to plan a menu. After discussing more specific needs with a pharmacist, he agreed to supply us at cost with multi-vitamins and special formulas for people who have serious vitamin and protein deficiencies. In the interests of a sustainable program, we specifically opted against receiving these products as a donation. With the present agreement, we can request further products as they are needed, knowing that the pharmacist, although not making a profit from these sales, is also not experiencing his assistance as a liability for his business. Although it is well-known that a healthy diet and the regular intake of vitamins cannot cure someone with HIV/AIDS, it can mean the difference between a child becoming an orphan at the age of three or becoming an orphan only a few years later. 


\section{FUTURE}

As the care-givers are confronted with new challenges in their work, the need for continued training is becoming increasingly important. Some of the training which will be undertaken in the near future includes basic counselling skills, the counselling of traumatised children, identifying and assisting sexually abused children and the ability to have a non-confrontational conversation with people about their relationship with Jesus Christ. As far as possible this training will be undertaken by people specialising in these fields. We have realised that there are many people who have specialised training and who would be willing to share their knowledge free of charge if they knew that this could make a real difference in people's lives.

But now that we have proven that we can make a difference in one community, we also need to expand the project. Throughout the Shiselweni district of Swaziland the Swaziland Reformed Church has small congregations. Using what has happened at Dwaleni as an example, the same process can now be duplicated in other areas, starting with sensitising the church members to the need within the community, identifying and training potential care-givers and then sending them out to become the hands and feet of Christ within their own communities.

\section{Consulted literature}

ACS 2006. National Overview - Swaziland <http://chemistry.org/portal/ resources/;jsessionid=\%405ef41\%3a10c62ead84c?id=1b2af8b4387911d7e47d6 ed9fe800100> (Accessed 12 July 2006).

Billinghurst, K G 2005. Initiating HIV AIDS community Programmes Bethal: PSASA.

Breetvelt, J 2006. Church, Theology and HIV/AIDS: African churches' involvement in the struggle against HIV/AIDS Deventer: PKN.

Christianity Today Editorial 2006. The AIDS Team < http://www.christianitytoday. com/ct/2006/008/3.14.html> (Accessed 27 July 2006).

ECS 2005. Common Country Assessment - Swaziland, $1997<$ http://www.ecs. co.sz/cca/cca_6.htm> (Accessed 12 July 2006).

Food and Agriculture Organization of the United Nations 2006. Food and Agriculture Indicators <http://www.fao.org/es/ess/compendium_2005/pdf/ ESS_SWA.pdf $>$ (Accessed 12 July 2006).

Go2africa 2006. Nhlangano <http://www.go2africa.com/swaziland/swazilandhlangano/>(Accessed 27 July 2006). 
Kaiser Family Foundation 2004. Swaziland Records World's Highest HIV/AIDS Prevalence, U.N. Envoy Says <http://www.kaisernetwork.org/daily_reports/ rep_index.cfm?DR_ID=22788> (Accessed 27 July 2006)

Kingdom of Swaziland 2002. 8th HIV Sentinel Serosurveillance Report Mbabane: Ministry of Health.

Nussbaum, Stan (ed) 2005. The Contribution of Christian Congregations to the Battle with HIV/AIDS at the Community Level Colorado Springs: GMI Research Services.

SAHIMS 2004. Country Information <http://www.sahims.net/swazirelief/ country_facts/country_fact_sheet.htm> (Accessed 12 July 2006).

Shilts, R 1988. And the Band played on - Politics, People, and the AIDS Epidemic New York: St.Martin's Press.

UNAIDS 2006a. 2006. Report on the Global AIDS Epidemic. Geneva: UNAIDS.

-, 2006b. Helping Ourselves: Community Responses to AIDS in Swaziland. Geneva: UNAIDS.

UNEP 2006. African Population Database Documentation <http://grid2. cr.usgs.gov/globalpop/africa/country-specific/r-z.html> (Accessed 12 July 2006).

UNICEF s.a. About us / Ngatsi. Swaziland: Colorpress.

Universiteit Utrecht 2003. Swaziland - historical demographical data of the whole country <http://www.library.uu.nl/wesp/populstat/Africa/swazilac.htm> (Accessed 12 July 2006)

Van Niekerk, Attie 1992. Sáám in Afrika. Kaapstad: Tafelberg.

Van Wyngaard, Arnau 2006. Towards a Theology of AIDS. REC Focus 6:1-2 (July), 51-75.

WHO 2004. UNAIDS/WHO Epidemiological Fact Sheet - 2004 Update. Geneva: WHO.

-, 2006. Swaziland <http://www.afro.who.int/wsh/countryprofiles/swaziland.pdf> (Accessed 12 July 2006).

Wilson, W \& Wilson I 2005. Lord, widen our territories <http:// www.globalministries.org/index.php?option=com_content\&task=view\&id=844 \&Itemid=30> (Accessed 12 July 2006).

World Council of Churches 2001. Plan of Action: The Ecumenical Response to HIV/AIDS in Africa. Global Consultation on the Ecumenical Response to the Challenge of HIV/AIDS in Africa, 1-10. 